\title{
A NOVEL METHOD FOR FAST ENRICHMENT AND MONITORING OF HEXAVALENT AND TRIVALENT CHROMIUM AT THE PPT LEVEL WITH MODIFIED SILICA MCM-41 AND ITS DETERMINATION BY INDUCTIVELY COUPLED PLASMA OPTICAL EMISSION SPECTROMETRY
}

\author{
Mohammad Reza Ganjali*, Leila Hajiagha Babaei, Alireza Badiei and Kamal Saberian \\ Department of Chemistry, Tehran University, Tehran, Iran \\ Seiedmahmoudreza Behbahani \\ Abureihan Higher Education Complex, Department of AgriculturalMachinery Technology, Tehran University, Tehran, Iran \\ Ghodsi Mohammadi Ziarani \\ Department of Chemistry, Alzahra University, Tehran, Iran \\ Masoud Salavati- Niasari \\ Department of Chemistry, Kashan University, Kashan, Iran
}

Recebido em 12/1/05; aceito em 25/8/05; publicado na web em 16/2/06

\begin{abstract}
Chromium(III) at the ng $\mathrm{L}^{-1}$ level was extracted using partially silylated MCM-41 modified by a tetraazamacrocyclic compound (TAMC) and determined by inductively coupled plasma optical emision spectrometry (ICP OES). The extraction time and efficiency, $\mathrm{pH}$ and flow rate, type and minimum amount of stripping acid, and break- through volume were investigated. The method's enrichment factor and detection limit are 300 and $45.5 \mathrm{pg} \mathrm{mL}^{-1}$, respectively. The maximum capacity of the $10 \mathrm{mg}$ of modified silylated MCM-41 was found to be $400.5 \pm 4.7 \mu \mathrm{g}$ for $\mathrm{Cr}(\mathrm{III})$. The method was applied to the determination of $\mathrm{Cr}(\mathrm{III})$ and $\mathrm{Cr}(\mathrm{VI})$ in the wastewater of the chromium electroplating industry and in environmental and biological samples (black tea, hot and black pepper).
\end{abstract}

Keywords: chromium; modified MCM-41; ICP OES.

\section{INTRODUCTION}

In recent years, the determination of chromium has received considerable attention. Chromium is usually found in natural waters in two different oxidation states, $\mathrm{Cr}(\mathrm{VI})$ and $\mathrm{Cr}(\mathrm{III})$. Both forms of chromium enter to the environment from various sources at the effluent discharge of tanning industries, electroplating, oxidative dying, cooling water power, chemical industry and steel works ${ }^{1,2}$. Depending on its oxidation state, the physiological effects of chromium on the biological systems are totally opposite. Chromium (III) is considered an essential element in mammals for the maintenance of glucose, lipid and protein metabolism, whereas $\mathrm{Cr}$ (VI) is considered to be a toxic material ${ }^{1,3,4}$, because of its ability to oxidize other species and its adverse impact on lung, liver and kidney. Owing to these two contrary effects, the precisely accurate determination of both species is essential. Due to the different properties and toxicity of the chemical forms of chromium, a great number of speciation studies have been performed ${ }^{5}$.

The direct determination of chromium in water may not be possible with sufficient sensitivity by also expensive analytical methods such as inductively coupled plasma atomic optical spectrometry (ICP OES) ${ }^{6}$ or electrothermal atomic absorption spectrometry (ETAAS) ${ }^{1}$ because of low concentrations and/or matrix interferences. For this purpose, various separation and pre-concentration methods such as liquid-liquid extraction ${ }^{1,6}$, coprecipitation $^{3,7}$, ion exchange $\mathrm{e}^{8-10}$ and adsorption ${ }^{11-14}$ have been developed. Sugiyama et $a l .{ }^{6}$ determined trace elements including chromium in natural waters by ICP OES after preconcentration by dithiocarbamate extraction. Subramainan ${ }^{1}$ developed a procedure using

*e-mail: Ganjali@khayam.ut.ac.ir
APCD-MIBK (Ammonium pyrrolidinedithiocarbamate Methylisobutyl ketone ) extraction system for the determination of $\mathrm{Cr}(\mathrm{III})$ and $\mathrm{Cr}(\mathrm{VI})$ by ETAAS. Isshiki et al. ${ }^{11}$ used macroporous polystyrenedivinylbenzene as an adsorbent for the preconcentration of chromium species. Demirata et al. used melamineformaldehyde for the same purposes ${ }^{13}$. Morocco et al. proposed a procedure for the preconcentration of $\mathrm{Cr}(\mathrm{VI})$ with tributyltin chloride immobilized on $\mathrm{C} 18 \mathrm{film}^{14}$. Some of these adsorbents may be fairly effective for pre-concentration by sorption of metal ions, but their methods of preparation are lengthy and involve rigid control of conditions.

The synthesis of a new form of mesoporus silica molecular sieves ${ }^{15,16}$, preparated using surfactants as organic templates, initiated a new field of research in material science. Among them, MCM-41 is the most studied. It possesses a uniform hexagonal array of linear channels constructed with a silica matrix like a honeycamb. The diameter of their channels can be tailored by using surfactants with different molecular size. Due to high surface area and large channel diameters, these materials attract much attention as a new host for large molecules ${ }^{17-19}$.

The major advantages of the modified MCM-41 include (1) very short sample processing time, $2 \mathrm{~min}$, due to the warm like of particles which allows the sample processing at very higher flow rates, (2) reduced channeling resulting from the use of uniform diameter sorbent with same length, $10 \mathrm{~mm}$, and a greater mechanical stability of the sorbent.

In this work, we wish to introduce a novel method for fast separation, preconcentration and ICP OES determination of ultra trace amounts of chromium in both states in biological, environmental and industrial samples. To the best our knowledge, this is the first application of modified MCM-41 with tetraazamacrocyclic compound (Figure 1) for separation and preconcentration of ultra trace amounts of chromium. 


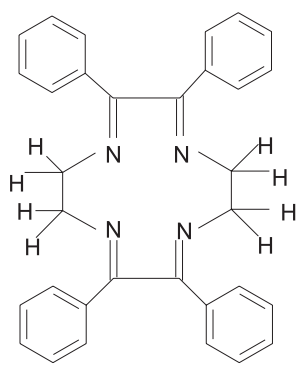

Figure 1. Structure of TAMC

\section{EXPERIMENTAL PART}

\section{Reagents}

Fumed silica (Cab-O-Sil Degussa), sodium silicate (Aldrich), and TMA-silicate (Sachem) were used for synthesis of silylated MCM-41. All organic solvents (HPLC grade) were from Merck Chemical Company. All acids used were of the highest purity available from Merck. Analytical grade nitrate salts of lead, sodium, potassium, magnesium, calcium, strontium, nickel, cadmium, copper and chromium (all from Merck) were of the highest purity available and used without any further purification. Doubly distilled deionized water was used throughout. The TAMC (tetraazomacrocyclic compound) was synthesized and purified as described elsewhere ${ }^{20}$.

\section{Synthesis of silylated MCM-41}

The MCM-41 was synthesized according to litrature ${ }^{21,22}$ using a gel composition (in mol) of $100 \mathrm{SiO}_{2}, 8.64 \mathrm{Na}_{2} \mathrm{O}, 4.38$ (TMA) $2 \mathrm{O}$, $31.24 \mathrm{CTMABr}$, and $6330 \mathrm{H}_{2} \mathrm{O}\left(\mathrm{TMA}^{+}=\right.$tetramethylammonium and $\mathrm{CTMABr}=$ cetyltrimethylammonium bromide). A clear gel was obtained after $10 \mathrm{~min}$ of stirring a mixture containing fumed silica (Cab-O-Sil Degussa), sodium silicate, and TMA-silicate in water. The addition of CTMABr was followed by vigorous stirring for 60 min. The so-obtained dense foam was maintained for $24 \mathrm{~h}$ at $100{ }^{\circ} \mathrm{C}$ in a Teflon-lined static autoclave. A white solid was filtered off and dried in air. A mass of $1.0 \mathrm{~g}$ of solid was treated under reflux at $100{ }^{\circ} \mathrm{C}$ in $20 \mathrm{ml}$ of a $1: 1$ mixure of hexamethyldisilazane and hexamethyldisiloxane (HMDSO) for one night. The silylated MCM41 was washed with ethanol and dried in air. The surfactant was removed from solid by $\mathrm{HCl} 0.1 \mathrm{~mol} \mathrm{~L}^{-1}$ in ethanol ${ }^{23}$.

\section{Modification of silylated MCM-41}

$100 \mathrm{mg}$ of TAMC was dissolved in $5 \mathrm{~mL}$ chloroform and then $20 \mathrm{mg}$ of silylated MCM-41 was added to the solution and the mixture was stirred for $5 \mathrm{~min}$. The resulting mixture was dried in air.

\section{Apparatus}

The chromium and other cations determination were carried out by ICP OES varian, model LIDERTY 150 AX Turbo.

Ultra trace amounts of chromium ion were determined by Gama spectrometry, Silena-Italy with HPGE detector. The XRD (X-ray Diffraction) was obtained from Siemens D500 diffractometer employing nickel filtrated $\operatorname{CuK} \alpha\left(\lambda=1.5418^{\circ} \mathrm{A}\right)$. The specific surface was determined from the linear part of BET plot $\left(\mathrm{p} / \mathrm{p}_{\mathrm{o}}=0.05\right.$ - 0.03) at $77 \mathrm{~K}$ using Omnisorb 100.

\section{Sample extraction}

The general procedure for extraction of $\mathrm{Cr}$ (III) ions by the modified MCM-41 was as follows. To $100 \mathrm{~mL}$ of the sample solution containing $2 \mu \mathrm{g} \mathrm{Cr}(\mathrm{III}), 10 \mathrm{mg}$ of modified MCM-41 was added and the mixture was stirred for at least $2 \mathrm{~min}$. Then, the resulting mixture was filterated on a paper filter.The extracted $\mathrm{Cr}$ (III) on the paper, was then stripped using $10 \mathrm{~mL}$ of $3.0 \mathrm{~mol} \mathrm{l}^{-1}$ solution of nitric acid into $10 \mathrm{~mL}$ volumetric flask and the chromium concentration was determined by ICP OES.

For separation and determination $\mathrm{Cr}(\mathrm{VI})$ must be coverted to $\mathrm{Cr}(\mathrm{III})$. Thus, before extraction, addition of $0.1 \mathrm{~mL}$ of sodium thiosulfate $\left(0.1 \mathrm{~mol} \mathrm{~L}^{-1}\right)$ to the solution is necessary. At first $\mathrm{Cr}(\mathrm{III})$ is determined after addition of sodium thiosulfate solution, $\mathrm{Cr}(\mathrm{VI})$ is reduced to $\mathrm{Cr}(\mathrm{III})$ and subsequently determined as total chromium; the difference gives the $\mathrm{Cr}(\mathrm{VI})$ present in sample.

\section{RESULTS AND DISCUSSION}

The XRD pattern of acid silylated MCM-41 washed reflects the high quality of hexagonal array ${ }^{15}$. The final product showed the BET surface area $800 \mathrm{~m}^{2} / \mathrm{g}$ and pore diameter $28^{\circ} \mathrm{A}$, based on adsorption-desorption of $\mathrm{N}_{2}$ at $77^{\circ} \mathrm{K}$.

The tetraazamacrocyclic compound (TAMC) with a rigid cavity and sufficient lipophilicity can form very selective complex with $\mathrm{Cr}$ (III) ion $^{24}$, and it was used as an excellent ionophore in construction of a highly selective and sensitive $\mathrm{Cr}$ (III) membrane sensor $^{24}$. Thus, we were interested to consider its ability as a suitable modifier for silylated MCM-41 in separation and pre-concentration of $\mathrm{Cr}$ (III) in different samples.

At the first, experiments were carried out in order to choose a proper eluent for the retained chromium after the extraction of $1 \mu \mathrm{g}$ $\mathrm{Cr}$ (III) in $100 \mathrm{ml}$ solution by the modified MCM-41, Chromium(III) was stripped with common inorganic and organic acids and results are given in Table 1. The data given in Table 1, revealed that among four different acid solutions used, $10 \mathrm{~mL}$ of $3.0 \mathrm{~mol} \mathrm{~L}^{-1}$ nitric acid can accomplish the quantitative elution of $\mathrm{Cr}$ (III) from the modified MCM-41, while other acids used are ineffective for the complete elution of $\mathrm{Cr}(\mathrm{III})$ from the modified MCM-41.

Table 1. Recovery of Cr(III) from the modified MCM-41 using different stripping acid solutions ${ }^{\mathrm{a}}$

\begin{tabular}{lcc}
\hline Stripping acid solution & $\begin{array}{c}\text { Volume } \\
(\mathrm{mL})\end{array}$ & $\begin{array}{c}\text { \% Recovery } \\
\text { of Cr (III) }\end{array}$ \\
\hline$\left(3 \mathrm{~mol} \mathrm{~L}^{-1}\right)$ & & \\
$\mathrm{HNO}_{3}$ & 20 & $99.9(0.5)^{\mathrm{b}}$ \\
$\mathrm{HNO}_{3}$ & 10 & $99.8(0.7)$ \\
$\mathrm{HNO}_{3}$ & 5 & $89.2(0.8)$ \\
$\mathrm{HOAc}$ & 10 & $72.7(1.2)$ \\
$\mathrm{HBr}$ & 10 & $76.6(1.1)$ \\
$\mathrm{HCl}$ & 10 & $71.1(0.9)$ \\
\hline
\end{tabular}

anitial samples contained $2 \mu \mathrm{g} \mathrm{Cr}(\mathrm{III})$ in $100 \mathrm{~mL}$ water; ${ }^{\mathrm{b}} \mathrm{RSD}$ based on three replicate analysis

In solid phase extraction, the extraction rate is very important. Thus, the effect of flow rates on extraction efficiency of the sample solution from the modified MCM-41 for the $\mathrm{Cr}$ (III) ion was investigated. It was found that, in the range of $20-200 \mathrm{~mL} \mathrm{~min}^{-1}$, the retention of $\mathrm{Cr}$ (III) by the modified MCM-41 is not affected by the sample solution flow rate. It should be noted that, this method is one of the faster method in solid phase extraction of cations from aqueous samples. 
The influence of extraction time on efficiency of extraction for a series of solutions containing $2 \mu \mathrm{g}$ of chromium was studied and the results showed that the time of extraction (from 2 to $60 \mathrm{~min}$ ) has not any effect on extraction efficiency of the ions.

To investigate the optimum amount of modified MCM-41 on the quantitative extraction of chromium, the extraction was conducted by varying amounts of the modified MCM-41 from 2$20 \mathrm{mg}$, and the results are summarized in Table 2. As it is obvious, the extraction of chromium is quantitative by using $10 \mathrm{mg}$ of modified MCM-41. Hence, subsequent extraction experiments were carried out with $10 \mathrm{mg}$ of modified MCM-41.

Table 2. Effect of amount modified MCM-41 on recovery of $\mathrm{Cr}$ (III) ion $^{\mathrm{a}}$

\begin{tabular}{cc}
\hline $\begin{array}{c}\text { Modified MCM-41 } \\
(\mathrm{mg})\end{array}$ & $\begin{array}{c}\text { \% Extraction } \\
\text { of Cr(III) }\end{array}$ \\
\hline 2 & $20.5(1.1)$ \\
4 & $41.2(1.0)$ \\
6 & $66.3(0.5)$ \\
8 & $91.2(0.5)$ \\
10 & $99.9(0.9)$ \\
20 & $99.1(0.7)$ \\
\hline
\end{tabular}

a Initial samples contained $2 \mu \mathrm{g} \mathrm{Cr}(\mathrm{III})$ in $100 \mathrm{~mL}$ water; ${ }^{\mathrm{b}} \mathrm{RSD}$ based on three replicate analysis

The effect of $\mathrm{pH}$ of aqueous samples on the extraction of $2 \mu \mathrm{g}$ $\mathrm{Cr}$ (III) from $100 \mathrm{~mL}$ solution was investigated in the range 2.0 to 10.0 (the $\mathrm{pH}$ was adjusted by using $0.1 \mathrm{~mol} \mathrm{~L}^{-1}$ of either nitric acid or sodium hydroxide solutions). The results are depicted in Figure 2. As it can be seen from Figure 2, the quantitative extraction of $\mathrm{Cr}(\mathrm{III})$ by the modified MCM- 41 is independent of $\mathrm{pH}$ in the range 4.0-10.0. At lower $\mathrm{pH}(<4.0)$, the nitrogen atoms of the TAMC could be some protonated and reduced the stability of complex formation between TAMC and $\mathrm{Cr}(\mathrm{III})$ ion.

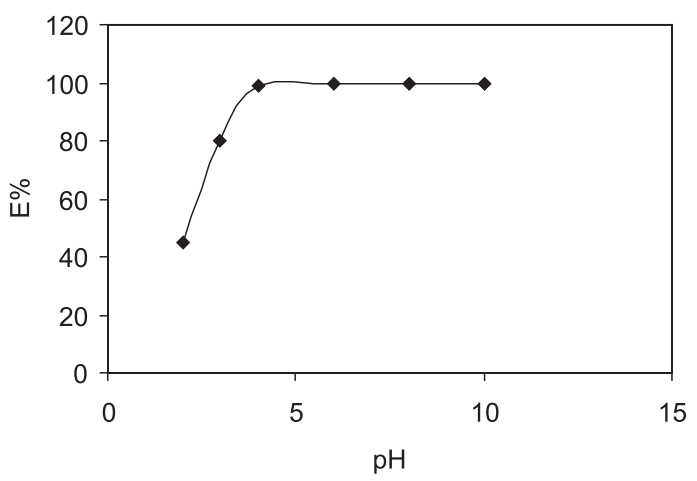

Figure 2. The effect of $\mathrm{pH}$ of the aqueous samples on the extraction of $\mathrm{Cr}(\mathrm{III})$

The break-through volume of the sample solution was tested by dissolving $2 \mu \mathrm{g}$ of the chromium in 100, 250, 500, 1000, 2000, 2500 and $3000 \mathrm{~mL}$ of water, and the recommended procedure was followed. In all cases, the extraction by modified membrane MCM41 was found to be quantitative. Thus the break-through volume for the method should be greater than $3000 \mathrm{~mL}$.

The limit of detection (LOD) and limit of quantification (LOQ) of the proposed method for the determination of chromium ion were studied under the optimal experimental conditions. The LOD and LOQ obtained ${ }^{25,26}$ from $\mathrm{C}_{\text {LOD }}=\mathrm{K}_{\mathrm{b}} \mathrm{S}_{\mathrm{b}} \mathrm{m}^{-1}$ and $\mathrm{C}_{\mathrm{LOQ}}=\mathrm{K}_{\mathrm{a}} \mathrm{S}_{\mathrm{b}} \mathrm{m}^{-1}\left(\mathrm{~S}_{\mathrm{b}}\right.$ is the standard deviation blank solution and $\mathrm{m}$ is the slope of calibration curve) for a numerical factor $\mathrm{K}_{\mathrm{b}}=3$ and $\mathrm{K}_{\mathrm{a}}=10$, and concentration factor of 300 are $45.5 \mathrm{pg} \mathrm{mL}^{-1}$ and $151.7 \mathrm{pg} \mathrm{mL}^{-1}$ respectively.
The maximum capacity of the $10 \mathrm{mg}$ modified MCM-41 was determined by passing $100 \mathrm{~mL}$ portions of an aqueous solution containing $1000 \mu \mathrm{g}$ chromium through the modified MCM-41, followed by determination of the retained chromium ions using ICP OES. The maximum capacity was found to be $400.5 \pm 4.7 \mu \mathrm{g}$ of chromium.

\section{Separation and determination of chromium in binary mixtures}

In order to investigate the selective separation and determination of chromium ions from water containing diverse metal ions, an aliquot of aqueous solution $(100 \mathrm{ml})$ containing $1 \mu \mathrm{g}$ chromium and various amounts of other cations was taken and the recommended procedure was followed, and the results are summarized in Table 3 . The results show that, the chromium ions in the binary mixtures are retained almost completely by the modified MCM-41.

Table 3. Extraction of $\mathrm{Cr}(\mathrm{III})$ and $\mathrm{Cr}(\mathrm{VI})$ from binary mixtures ${ }^{\mathrm{a}}$

\begin{tabular}{lccc}
\hline $\begin{array}{l}\text { Diverse } \\
\text { ion }\end{array}$ & $\begin{array}{c}\text { Amount } \\
\text { taken }(\mu \mathrm{g})\end{array}$ & $\begin{array}{c}\text { \% Extraction of } \\
\mathrm{Cr}(\mathrm{III})\end{array}$ & $\begin{array}{c}\text { \% Extraction of } \\
\mathrm{Cr}(\mathrm{VI})\end{array}$ \\
\hline $\mathrm{Na}^{+}$ & 100000 & $99.7(0.4)$ & $99.8(1.4)^{\mathrm{b}}$ \\
$\mathrm{K}^{+}$ & 100000 & $99.9(0.5)$ & $99.6(1.0)$ \\
$\mathrm{Mg}^{2+}$ & 100000 & $100.0(0.9)$ & $100.0(1.2)$ \\
$\mathrm{Ca}^{2+}$ & 100000 & $100.2(0.8)$ & $99.9(1.1)$ \\
$\mathrm{Sr}^{2+}$ & 100000 & $100.0(1.2)$ & $100.1(1.0)$ \\
$\mathrm{Cd}^{2+}$ & 5000 & $99.9(0.7)$ & $99.6(1.2)$ \\
$\mathrm{Ni}^{2+}$ & 5000 & $99.8(0.5)$ & $99.8(1.0)$ \\
$\mathrm{Cu}^{2+}$ & 5000 & $100.0(0.9)$ & $99.7(1.2)$ \\
$\mathrm{Pb}^{+2}$ & 5000 & $99.7(0.7)$ & $100.0(0.8)$ \\
\hline
\end{tabular}

${ }^{a}$ Initial samples contained $1 \mu \mathrm{g} \mathrm{Cr}(\mathrm{III})$ and $1 \mu \mathrm{g} \mathrm{Cr}(\mathrm{VI})$ in $100 \mathrm{~mL}$ water; ${ }^{\mathrm{b}} \mathrm{RSD}$ based on three replicate analysis

\section{Speciation of $\mathrm{Cr}(\mathrm{III})$ and $\mathrm{Cr}(\mathrm{VI})$ in wastewater}

The proposed method was used for speciation of both case of chromium in two different wastewater samples (Electroplatig factory, Tehran, Iran), and the results are given in Table 4. As it can be seen, the results obtained by the proposed method and Gama Spectrometry are in satisfactory agreement.

Table 4. Determination of hexavalent and trivalent chromium in wastewater samples

\begin{tabular}{lcccc}
\hline Sample & \multicolumn{2}{c}{ Cr(III) $\left(\mathrm{ng} \mathrm{g}^{-1}\right)$} & \multicolumn{2}{c}{ Cr(VI) $\left(\mathrm{ng} \mathrm{g}^{-1}\right)$} \\
& SPE-ICP OES & G-S & SPE-ICP OES & G-S \\
\hline 1 & $1.7(0.4)^{\mathrm{a}}$ & $1.5(0.5)$ & $109.5(0.9)$ & $109.0(0.7)$ \\
2 & $2.2(0.3)$ & $2.1(0.4)$ & $191.9(0.8)$ & $192.2(0.7)$ \\
\hline
\end{tabular}

${ }^{a}$ RSD based on three replicate analysis

\section{Determination of chromium in black tea}

The proposed method was also applied to determination of chromium in two black tea samples. The procedure used for the extraction of cations from samples was similar to that reported in the literature ${ }^{27} .100 \mathrm{mg}$ of dry sample (dried at $110^{\circ} \mathrm{C}$ ) was placed in a $50 \mathrm{~mL}$ beaker, followed by the addition of $7 \mathrm{~mL}$ of concentrated nitric acid, and the beaker was covered with a glass watch. The beaker was allowed to stand over night, and the contents were heated on a hot plate $\left(150{ }^{\circ} \mathrm{C}\right.$ for $\left.15 \mathrm{~min}\right)$. Then the sample was cooled, $8 \mathrm{~mL}$ of 
perchloric acid was added, and the mixture was heated again at $200{ }^{\circ} \mathrm{C}$ until the solution became clear (about $1 \mathrm{~h}$ ). The glass watch was removed and the acid evaporated to dryness at $250{ }^{\circ} \mathrm{C}$. The white residue was completely dissolved in $5 \mathrm{~mL}$ of $1 \mathrm{~mol} \mathrm{~L}^{-1}$ nitric acid and the solution was transferred to a $100 \mathrm{~mL}$ calibrated flask. 0.1 $\mathrm{mL}$ sodium thiosulfate $\left(0.1 \mathrm{~mol} \mathrm{~L}^{-1}\right)$ was added to this solution, and then, the solution was neutralized with a proper $\mathrm{NaOH}$ solution and the solution was diluted to the mark, and the recommended procedure was followed. The results are shown in Table 5. As it can be seen, the amount of the total chromium in black tea samples can be accurately determined with the proposed method.

Table 5. Determination of total chromium in black tea, hot and black pepper samples

\begin{tabular}{|c|c|c|c|c|}
\hline \multirow[t]{2}{*}{ Sample } & \multicolumn{2}{|c|}{$\mathrm{Cr}(\mathrm{III})\left(\mathrm{ng} \mathrm{g}^{-1}\right)$} & \multicolumn{2}{|c|}{$\mathrm{Cr}(\mathrm{VI})\left(\mathrm{ng} \mathrm{g}^{-1}\right)$} \\
\hline & SPE-ICP OES & G-S & SPE-ICP OES & G-S \\
\hline $\begin{array}{l}\text { Iranian } \\
\text { black tea } \\
\text { (Lahijan) }\end{array}$ & $3.68(0.5)^{\mathrm{a}}$ & $3.57(0.4)$ & $0.04(0.02)$ & $0.03(0.01)$ \\
\hline $\begin{array}{l}\text { Indian } \\
\text { black tea } \\
\text { (Seylon) }\end{array}$ & $3.35(0.3)$ & $3.50(0.3)$ & $0.05(0.02)$ & $0.05(0.02)$ \\
\hline $\begin{array}{l}\text { Black } \\
\text { pepper }\end{array}$ & $6.88(0.8)$ & $6.52(0.7)$ & $0.07(0.03)$ & $0.08(0.03)$ \\
\hline $\begin{array}{l}\text { Hot } \\
\text { pepper }\end{array}$ & $8.47(0.5)$ & $8.41(0.5)$ & $0.09(0.03)$ & $0.09(0.02)$ \\
\hline
\end{tabular}

${ }^{a}$ RSD based on three replicate analysis

\section{Determination of chromium in black and hot pepper}

A $10 \mathrm{mg}$ pepper was taken in a beaker and dissolved in concentrated nitric acid $(5 \mathrm{~mL})$ with heating. The solution was cooled, neutralized with $\mathrm{NaOH}$ solution, diluted and filtered. The filtrate was made to $100 \mathrm{~mL}$ with water in a calibrated flask. An aliquot (10-20 mL) of the sample solution was taken and the total chromium was determined by the general procedure. The results are given in Table 5. As it can be seen the results obtained by the proposed method and Gama Spectrometry are in satisfactory agreement.

\section{Comparison of the proposed method with the previously reported methods}

Table 6 compares the performance characteristics of the proposed method, with those of the previously reported preconcentration methods. As it is obvious, the proposed method not

Table 6. Comparison of concentration factor, detection limit, and extraction rate of the propose method and the best reported methods

\begin{tabular}{|c|c|c|c|c|}
\hline Method & $\begin{array}{c}\text { Concentration } \\
\text { Factor }\end{array}$ & $\begin{array}{c}\text { Detection } \\
\text { limit } \\
\left(\mu \mathrm{g} \mathrm{L}^{-1}\right)\end{array}$ & $\begin{array}{l}\text { Extraction } \\
\text { rate } \\
\left(\mu \mathrm{L} \min ^{-1}\right)\end{array}$ & Ref. \\
\hline 1 & 25 & 45 & 1.5 & 28 \\
\hline 2 & - & 500 & 3.5 & 29 \\
\hline 3 & - & 2 & 3.4 & 30 \\
\hline 4 & 50 & 2.5 & $(10 \mathrm{~min})$ & 31 \\
\hline $5 \mathrm{Cr}(\mathrm{III})$ & 86 & 0.025 & 2.5 & 32 \\
\hline $\mathrm{Cr}(\mathrm{VI})$ & 50 & 0.020 & 2.5 & - \\
\hline This work & 300 & 0.045 & $(5 \mathrm{~min})$ & - \\
\hline
\end{tabular}

only in the term of the concentration factor, but also in the terms of detection limit and the extraction rate, are superior to those previously reported.

\section{CONCLUSIONS}

The proposed method has the following advantages: The method is fast, it can selectively separate $\mathrm{Cr}$ (III) ions from other metal ions associated, even much higher concentrations, and it can be successfully applied to separation, speciation and determination of ultra trace amounts of $\mathrm{Cr}(\mathrm{III})$ and $\mathrm{Cr}(\mathrm{VI})\left(45.5 \mathrm{pg} \mathrm{mL}^{-1}\right)$ using partial silylated MCM-41 modified by tetraazamacrocyclic compound and ICP OES. The method was used for determination of $\mathrm{Cr}(\mathrm{III})$ and $\mathrm{Cr}(\mathrm{VI})$ in industrial, biological and environmental samples.

\section{ACKNOWLWGGEMENTS}

The author thanks the Tehran University Research Council for support of this work.

\section{REFERENCES}

1. Subramanian, K. S.; Anal. Chem. 1988, 60, 11.

2. Sperling, M.; Xu, S.; Welz, B.; Anal. Chem. 1992, 64, 3101.

3. Lan, C. R.; Tseng, C. L.; Yang, M. H.; Analyst 1991, 116, 35.

4. Gaspar, A.; Posta, J.; Toth, R.; J. Anal. At. Spectrom. 1996, 11, 1067.

5. Nusko, R.; Heuman, K. G.; Fresenius J. Anal. Chem. 1997, 357, 1050.

6. Sugiyama, M.; Fujino, O.; Kihara, S.; Matsui, M.; Anal. Chim. Acta 1986, $181,159$.

7. Boughriet, A.; Deram, L.; Wartel, M.; J. Anal. At. Spectrom. 1994, 9, 1135.

8. Johnson, C. A.; Anal. Chim. Acta 1990, 238, 273.

9. Milac;ic, R.; Stupar, J.; Koz;uh, N.; Koros;in, J.; Analyst 1992, 117, 125.

10. Yoshimura, K.; Analyst 1988, 113, 471.

11. Isshiki, K.; Sohrin, Y.; Karatani, H.; Nakayama, E.; Anal. Chim. Acta 1989, 224, 55.

12. Bag, H.; Turker, A.R.; Lale, M.; Tunceli, A.; Talanta 2000, 51, 895.

13. Demirata, B.; Tor, I.; Filik, H.; Afsar, H.; Fresenius J. Anal. Chem. 1996, 356, 375.

14. Morocco, M. T.; Newman, G. P.; Syty, A.; J. Anal. At. Spectrom. 1990, 5 , 29.

15. Kresge, C. T.; Leonowicz, N. E.; Vartuli, J. C.; Roth, W. J.; Beck, J. S.; Nature 1992, 359, 710

16. Beck, J. S.; Vartuli, J. C.; Roth, W.J.; Leonowicz, N.E.; Kresge, C. T.; Schmitt, K. D.; Chu, C. T. W.; Olson, D. H.; Scheppard, E. W.; McCullem, C. B.; Higgins, J. B.; Schlenker, J. L.; J. Am. Chem. Soc. 1992, 114, 10834.

17. Brunel, D.; Bellocq, N.; Sutra, P.; Cauvel, A.; Lasperas, M.; Moreau, P.; DiRenzo, F.; Galarneau, A.; Fajula, F.; Coord. Chem. Rev. 1998, 178, 1085.

18. Sorokin, A. B.; Tuel, A.; Catal. Today 2000, 57, 45.

19. Corriu, R. J. P.; Lancelle-Beltran, E.; Mehdi, A.; Reye, C.; Brandes, S.; Guilard, R.; J. Mater. Chem. 2002, 12, 1355.

20. Varshiney, A.; Tandon, J. P.; Polyhedron 1986, 5, 1853.

21. Reddy, K. M.; Song, C.; Catal. Lett. 1996, 36, 103.

22. Badiei, A.; Bonneviot, L.; Inorg. Chem. 1998, 37, 4142.

23. Badiei, A.; Cantournet, S.; Morin, M.; Bonneviot, L.; Langmuir 1998, 14, 7087.

24. Ganjali, M. R.; Mizani, F.; Salavati-Niasari, M.; Javanbakht, M.; Anal. Sci. 2003, 19, 235.

25. ACS Committee on Enviromental Improvement; Anal. Chem. 1980, 52, 2242 .

26. Ingle, J. D.; Crouch, S. R.; Spectrochemical Analysis, Prentice Hall: Englewood Cliffs, NJ, 1988.

27. Ichinoki, S.; Yamazaki, M.; Anal. Chem. 1985, 57, 2219.

28. Tunceli, A.; Rehber, T. A.; Talanta 2002, 57, 1199.

29. Kubota, L. T; Gushikem, Y.; Analyst 1991, 116, 281.

30. Peixoto, C. R. M.; Gushikem, Y.; Baccan, N.; Analyst 1992, 117, 1029.

31. Soylak, M.; Divrikli, U.; Elci, L.; Dogan, M.; Talanta 2002, 56, 565.

32. Posta, J.; Gaspar, A.; Toth, R.; Ombodi, L.; Microchem. J. 1996, 54, 195. 